Review Article

\title{
Regenerative Endodontic Therapy in the Management of Immature Necrotic Permanent Dentition: A Systematic Review
}

\author{
Faisal T. Alghamdi $\mathbb{i D}^{1}$ and Alaa E. Alqurashi ${ }^{2}$ \\ ${ }^{1}$ Department of Oral Biology, Faculty of Dentistry, King AbdulAziz University, Jeddah 80209, Saudi Arabia \\ ${ }^{2}$ Ibn Sina National College for Medical Studies, Dental College, Jeddah 22421, Saudi Arabia \\ Correspondence should be addressed to Faisal T. Alghamdi; dr.faisal2020@hotmail.com
}

Received 6 May 2020; Revised 22 June 2020; Accepted 27 June 2020; Published 13 July 2020

Academic Editor: Gianandrea Pasquinelli

Copyright (C) 2020 Faisal T. Alghamdi and Alaa E. Alqurashi. This is an open access article distributed under the Creative Commons Attribution License, which permits unrestricted use, distribution, and reproduction in any medium, provided the original work is properly cited.

\begin{abstract}
Background and Objective. Management of immature permanent teeth exhibiting necrotic pulp is clinically challenging. An appropriate diagnosis, case selection, and good management ensure good outcomes. The objective of this review reviews all up-to-date data in regard to endodontic regeneration therapy in the management of immature permanent teeth with necrotic pulp and which conducts are most used and appropriate for this procedure in human and animal investigations. Materials and Methods. The electronic databases PubMed and Google Scholar were used to search the literature for relevant studies after applying specific inclusion and exclusion criteria. Studies that fulfilled both the inclusion and exclusion criteria were included in this systematic review. The search was conducted by two independent reviewers following the PRISMA guidelines. Results. Only 46 studies that fulfilled both the inclusion and exclusion criteria, which were conducted within the last 10 years, were included in this systematic review. These studies investigated different aspects of regenerative endodontic therapy including different types of scaffolds, intracanal medications, pulpal space/barriers, root maturation stage, follow-up duration, and updated studies on their use in the management of immature necrotic permanent teeth. Conclusions. This review concluded the compiled data observed that endodontic regenerative therapy was more efficient in treating immature necrotic permanent teeth and offered a greater advantage that should lead to wider acceptance among endodontists for effective results compared to different treatment options. However, more clinical trials with a standardized protocol and defined clinical, radiographic, and histopathological outcomes with longer follow-up periods are warranted.
\end{abstract}

\section{Introduction}

Regenerative endodontic treatment (RET) is a common category of biologically based endodontic therapy known as revascularization or revitalization; RET aims to promote normal physiological development in immature permanent teeth with pulpal necrosis $[1,2]$. Resolution of apical periodontitis, retrogression of associated clinical symptoms, and prolonged survival of teeth are other important outcomes of RET [2-4], which are favored in children and young individuals as a viable alternative to traditional (nonregenerative) endodontic procedures [2].

In regard to immature necrotic permanent teeth, there are many treatment options for immature nonvital teeth, including periapical surgery and apexification using calcium hydroxide $\left(\mathrm{Ca}(\mathrm{OH})_{2}\right)$ and mineral trioxide aggregate (MTA) or biodentin [5-7]. The apexification was used as a treatment option for many years, which induces the formation of a calcific barrier at the apex by using intracanal calcium hydroxide $\left(\mathrm{Ca}(\mathrm{OH})_{2}\right)$. In spite of the extensive use of the $\mathrm{Ca}(\mathrm{OH})_{2}$-based apexification procedure, the long procedure time might require several visits and reestablishment of the intracanal dressing $[8,9]$, arbitrariness of the apical closure [10], and the predisposition of cervical root fractures after extended exposure to $\mathrm{Ca}(\mathrm{OH})_{2}$ [11] have raised earnest disquiet about the eligibility of this procedure technique. Up-to-date, the conventional apexification technique has been adjusted by the presentation of artificial apical barrier methods with mineral trioxide aggregate (MTA) [12-14]. The MTA approach enhances patient compliance and good outcomes to assist in the healing of the periapical tissues, although a shorten treatment period $[12,13,15,16]$; on the 
other hand, unfortunately, the improvement of the apical closure and intensification of radicular dentin still cannot be achieved by this approach $[10,11]$. Based on these considerations, it may be the apexification in future treatment protocols for nonvital immature permanent teeth illustrates to be dubitable $[17,18]$.

The idea of endodontic regeneration as a treatment option was favored especially after two authors in 2004; they illustrated a new technique for the management of immature permanent teeth with apical periodontitis and termed it "revascularization" [19]. The endodontic society found that "Pulp revascularization" was a significant advance to investigate tracks of pulp and dentin regeneration [20, 21]. Revascularization depends on the stem cells and growth factors by stimulating them to complete the apex closure. It is widely used when the opening diameter of the root canal is large [22]. Moreover, revascularization treatment enhanced root elongation and maturation [23].

There are many investigations which confirmed the success rate of the regenerative endodontic procedure conducted on children and young individuals, but the present evidence is still disputable in regards to the regenerated tissue and regenerative protocol. Few systematic review studies are available for the management of these teeth by regenerative endodontic treatment. Therefore, this current systematic review aims to compile all up-to-date information that investigated endodontic regeneration therapy in the management of immature permanent teeth with necrotic pulp and which conducts are most used and appropriate for this procedure in human and animal investigations.

\section{Materials and Methods}

This systematic review was designed and executed under the PRISMA guidelines [24].

2.1. Literature Search Strategy. Bibliographical searches were carried out in PubMed and Google Scholar databases in December 2019 and then updated in May 2020, using the Mesh terms, which were combined with Boolean operators (“AND" and "OR"). The following search strategies were used: "immature teeth" OR "immature tooth" OR “immature dentition" OR “immature permanent teeth" OR "immature permanent tooth," AND "young permanent teeth" OR "young permanent tooth," AND "pulp revascularization" OR "pulpal regeneration" OR "pulp revitalization" OR "root canal revascularization" OR "root maturation" OR "regenerative endodontic" OR "regenerative endodontic therapy" OR "regenerative endodontic treatment" OR "regenerative endodontic procedure," AND "blood clot" OR "platelet-rich fibrin" OR "platelet-rich plasma," AND “calcified barrier" OR "apical closure" OR "root end formation" OR "root apex closure" OR "apical plug” OR "MTA plug” OR "apexification" OR "mineral trioxide aggregate" OR "calcium hydroxide." The search database was examined by both examiners, and the final decision for inclusion and exclusion was made according to the following criteria. Studies that meet the following inclusion criteria were considered eligible: (1) published studies between the 10 years (2009-2019); (2) original research articles in the English language; and (3) studies performed on human and animal subjects. The following were considered as exclusion criteria: (1) published studies that assessed regenerative endodontic therapy but excluded immature necrotic permanent teeth; (2) studies that discuss the management of immature necrotic permanent teeth but excluded their effect on root closure or development; and (3) review articles on the management of immature nonvital permanent teeth.

2.2. Critical Appraisal. All reviewers independently screened the titles and abstracts of retrieved articles according to the eligibility criteria as well as PRISMA guidelines. Disagreements or inconsistencies were resolved through discussion and consensus among the two reviewers.

2.3. Data Extraction. The data were checked for completeness, accuracy, and extracted into standardized Microsoft Office Excel worksheets by both reviewers on an independent basis by fully reading the articles and considering the following variables: title, abstract, material and methods (number of subjects (teeth), type of intracanal medication, scaffolds, pulpal space/barrier, root maturation stage, and follow-up duration), and main results.

2.4. Data Items. Data from the included articles were collected and organized in columns as the following:

2.4.1. Human Studies. These studies include the following information: author and year, age of the patient with mean and standard deviation, number of subjects (teeth), type of intracanal medication, scaffolds, pulpal space/barrier, root maturation stage, follow-up duration, and main outcomes.

2.4.2. Animal Studies. These studies include the following information: author and year, animal species, number of subjects (teeth), type of intracanal medication, scaffolds, pulpal space/barrier, root maturation stage, follow-up duration, and main outcomes.

2.5. Assessment of Methodological Quality. As part of the data extraction process, two review authors assessed the risk of bias of the included studies. The methodological quality of each study was performed by using the risk of a bias assessment tool outlined in the Cochrane Handbook for Systematic Reviews of Interventions (Version 5.1.0) [25].

2.6. Synthesis of Results. As mentioned, tables were prepared with the fields included as data items.

2.7. Statistical Analysis. Parametric data involving the age of the patients of the human studies are presented as mean and standard deviation $(\mathrm{M} \pm \mathrm{SD})$. Thus, only a descriptive evaluation is presented. 


\section{Results and Discussion}

\subsection{Results}

3.1.1. Study Selection. Among the 7403 articles selected through the keywords using the databases, duplicated or unrelated records $(N=6165)$ were excluded; only 181 articles were initially listed according to the inclusion and exclusion criteria. Finally, 46 articles were selected to include in this systematic review. The summary of the selection process of the articles in this systematic review is delineated in Figure 1.

3.1.2. Study Characteristics. The search culminated in fortysix studies that fulfilled both the inclusion and exclusion criteria. The review included randomized controlled trials, controlled clinical trials, case reports, in vitro with in vivo studies, in vivo studies, and prospective/retrospective studies comparing the effectiveness of pulp revascularization in immature necrotic permanent teeth $[3,4,6,16,20,22,26-65]$. The studies included in this systematic review were 31 human studies $[3,4,6,16,20,22,26-31,35,39,40,44-47,50-53$, $55-57,59,60,63-65]$ and 15 animal studies [32-34, $36-38,41-43,48,49,54,58,61,62]$. This systematic review evaluated 46 studies that included a study sample of 1006 subjects (teeth). The human studies included patients of children and young individuals (aged between 7 and 18 years) with a mean age (mean \pm SD) $10.1 \pm 3.18$ years and selected from different dental clinics, hospitals, and dental schools $[3,4,6,16,20,22,26-31,35,39,40,44-47,50-53,55-57$, $59,60,63-65]$. On the other hand, most of the samples in animal studies included different species such as ferrets, sheep, dogs, and monkeys [32-34, 36-38, 41-43, 48, 49, $54,58,61,62]$. Among the included studies, six studies illustrated negative outcomes in regard to endodontic regeneration therapy in the management of immature necrotic permanent teeth $[29,34,46,48,49,54]$. On the other hand, 40 studies showed significant positive outcomes for endodontic regeneration treatment in these kinds of teeth due to root development, root wall thickening, root lengthening, and formation of hard tissue barrier or apical closure $[3,4,6,16,20,22,26-28,30-33,35-45,47,50-53,55-65]$. The outcomes of these 46 studies include different types of intracanal medications, scaffolds, pulpal space/barrier, root maturation stage, follow-up duration, and updating studies on their effect in periapical periodontitis and periapical healing. Table 1 provides a summary of the included human studies in this systematic review. An informative description of the included animal studies and their main outcomes are summarized in Table 2.

3.1.3. Quality and Risk Assessment of the Included Studies. The quality and risk assessment of all the included studies were conducted by two authors and are represented in Table 3. Included studies were assessed following the Cochrane collaboration's tool [25] for assessing the risk of bias. Summarizing, no single study was classified as a high risk of bias, and most studies demonstrated low or unclear risk of bias (Table 3).
3.2. Discussion. This systematic review was conducted to summarize and appraise all appreciated studies published within the last 10 years and fulfilled our study aim. This current systematic review aimed to compile all up-to-date information that investigated endodontic regeneration therapy in the management of immature permanent teeth with necrotic pulp and which conducts are most used and appropriate for this procedure in human and animal investigations. Our study presents a comprehensive compilation of evidence taken from 46 articles that met our inclusion and exclusion criteria.

Up-to-date, we can only find two old systematic reviews that talked about endodontic regenerative therapy in the management of immature necrotic teeth for human and animal studies (Table 4) [66,67]. Bucchi et al. concluded in their systematic review that most of the retrieved studies about clinical protocols of endodontic regenerative treatment suggest their effectiveness in the management of these kinds of teeth, however, most of the studies were found to support specific irrigation and intracanal dressings to better clinical, histological, and radiographic outcomes in endodontic regeneration for clinical human and animal studies [66]. In contrast, although Antunes et al. focused only on 11 articles in regards to pulp revascularization, their results confirm the clinical success of this procedure. In addition, the ability of this procedure is to activate the apical closure formation and increase the thickening of radicular dentin, but the key factors of tissue repair, the type of tissue formed, and the long-term prognosis are still not clear in different clinical studies [67]. This clearly shows the discrepancies in the conclusions between the previously published systematic reviewers. This may be mainly due to the differences in the applied inclusion and exclusion criteria in addition to the authors' opinions. However, we could find some studies to support the high success rates for the use of endodontic regenerative therapy in the management of immature necrotic permanent teeth in human and animal studies compared with previously published systematic reviews. In addition, the first review [66] covered the period time from 2007 to 2016 and the second review [67] covered the period time from 2008 to 2014 (Table 4); thus, our systematic review covered all eligible articles published within the last decade ((Table 1) and (Table 2)).

In our updated systematic review, all 46 studies favored the use of different scaffolds in endodontic regenerative therapy in the management of immature necrotic permanent teeth ((Table 1) and (Table 2)). The majority of these studies used blood clot (induced bleeding) as a scaffold in this procedure ((Table 1) and (Table 2)). Hence, the three scaffolds such as blood clot (induced bleeding), platelet-rich plasma (PRP), and platelet rich fibrin (PRF) have a vital role to stimulate pulp revascularization and associate to the treatment of immature necrotic permanent teeth [68]. In regards to the different types of intracanal medications and pulpal space/barriers used in this procedure, most of the investigations in this review used triple-antibiotics paste (TAP) as an intracanal medication and mineral trioxide aggregate (MTA) as the pulpal space/barrier due to their effectiveness in pulp revascularization to treat the immature 


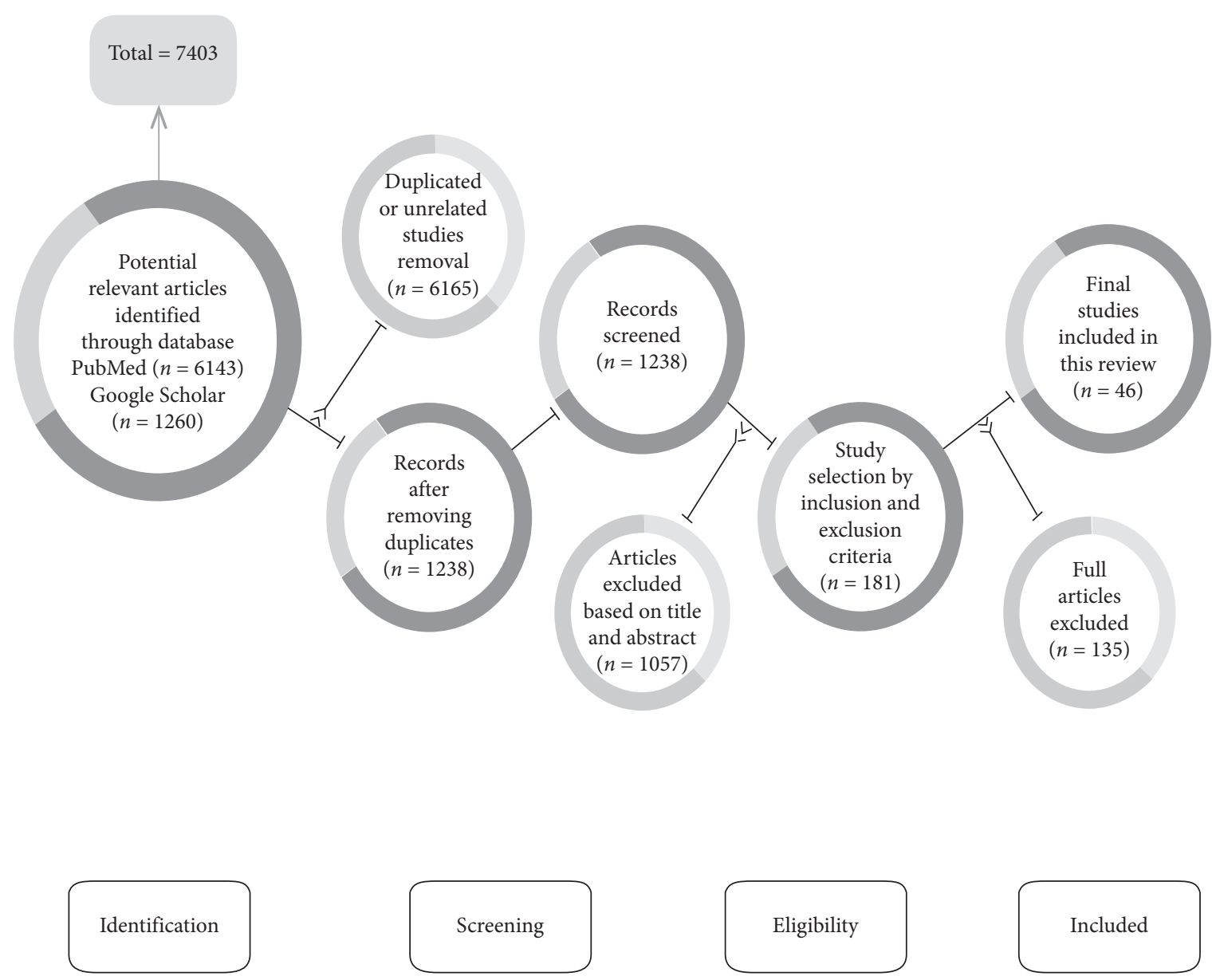

FIGURE 1: Flowchart outlining the protocol adopted in the systematic review based on the preferred reporting items for systematic reviews and meta-analyses (PRISMA) guidelines.

necrotic permanent teeth in comparison with other intracanal medications and pulpal space/barriers ((Table 1) and (Table 2)). Most of the studies included in this review do not use any classification system to determine the degree of root formation and maturation. Each study has measured the percentage of root length and width changes to determine root maturation ((Table 1$)$ and (Table 2$)$ ). In our review, we used a specific classification system to evaluate the degree of root formation and maturation based on these root length and width changes among the included studies ((Table 1) and (Table 2)). This classification is called "Cvek's Classification," concerning root formation and maturation [69]. The Cvek's classification system was used in this systematic review due to didactic radiographic characteristics of this system, which allow for a better clinical application than that used in the other classification schemes [69]. This Cvek's classification system was used to determine the root maturation stage in the following five stages concerning the level of root maturity: stage $I=$ less than $1 / 2$ root length, stage $I I=1 / 2$ root length, stage III $=2 / 3$ root length, stage IV = wide open apical foramen and nearly complete root length, and stage $\mathrm{V}=$ closed apical foramen and completed root development. Moreover, the teeth in stage $\mathrm{V}$ were considered mature and fully apical formed teeth, and the other four stages (stages I, II, III, and IV) described teeth with open apices and lack of apical constriction development but with some significant morphological differences [69]. Among the 31 human studies in this review, 26 studies showed partially or completely mature teeth (Cvek stages IV and V), 3 studies showed teeth with intermediate root development (Cvek stage III), and 2 studies showed teeth with an initial stage of root development (Cvek stages I and II) (Table 1). In contrast, among the 15 animal studies, 10 studies were classified as Cvek stages IV and V, followed by 1 study classified as Cvek stage III, 3 studies showed teeth with an initial stage of root development (Cvek stages I and II), and one study was not reported in regard to the root maturation stage (Table 2). Therefore, regenerative endodontic therapy has the potential to induce the root maturation of necrotic immature permanent teeth and illustrate a significant increase in root length and dentinal wall thickness in most of the included studies in this review ((Table 1) and (Table 2)). Although all these studies were carried out on human and animal models, we need more studies to be conducted to strengthen the evidence of these studies; thus, we will be very close to finally give this procedure the superiority in treating immature necrotic permanent teeth compared with other treatment options.

Studies included in this review illustrated varied followup times for endodontic regeneration therapy in the management of these kinds of teeth ((Table 1) and (Table 2)). 


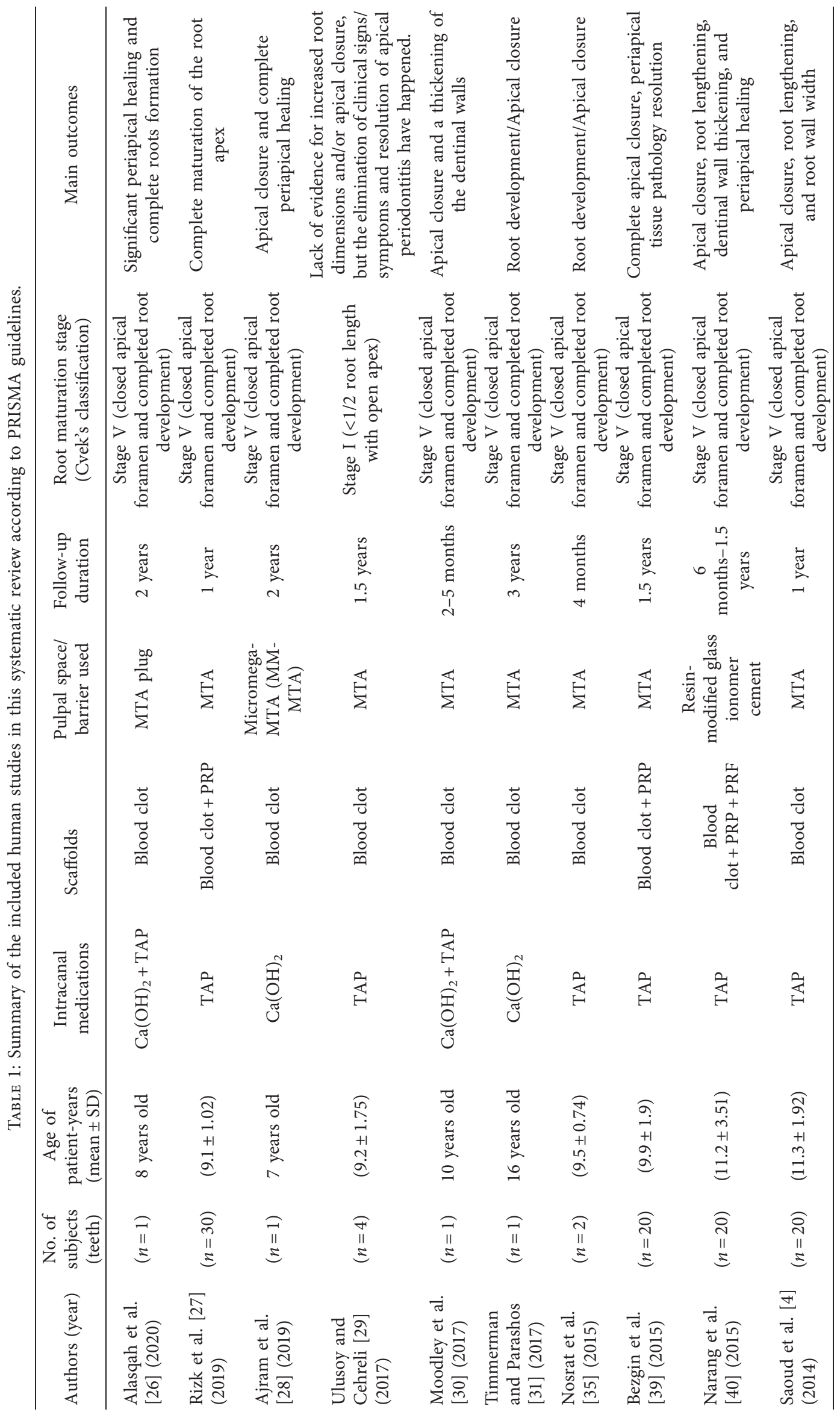




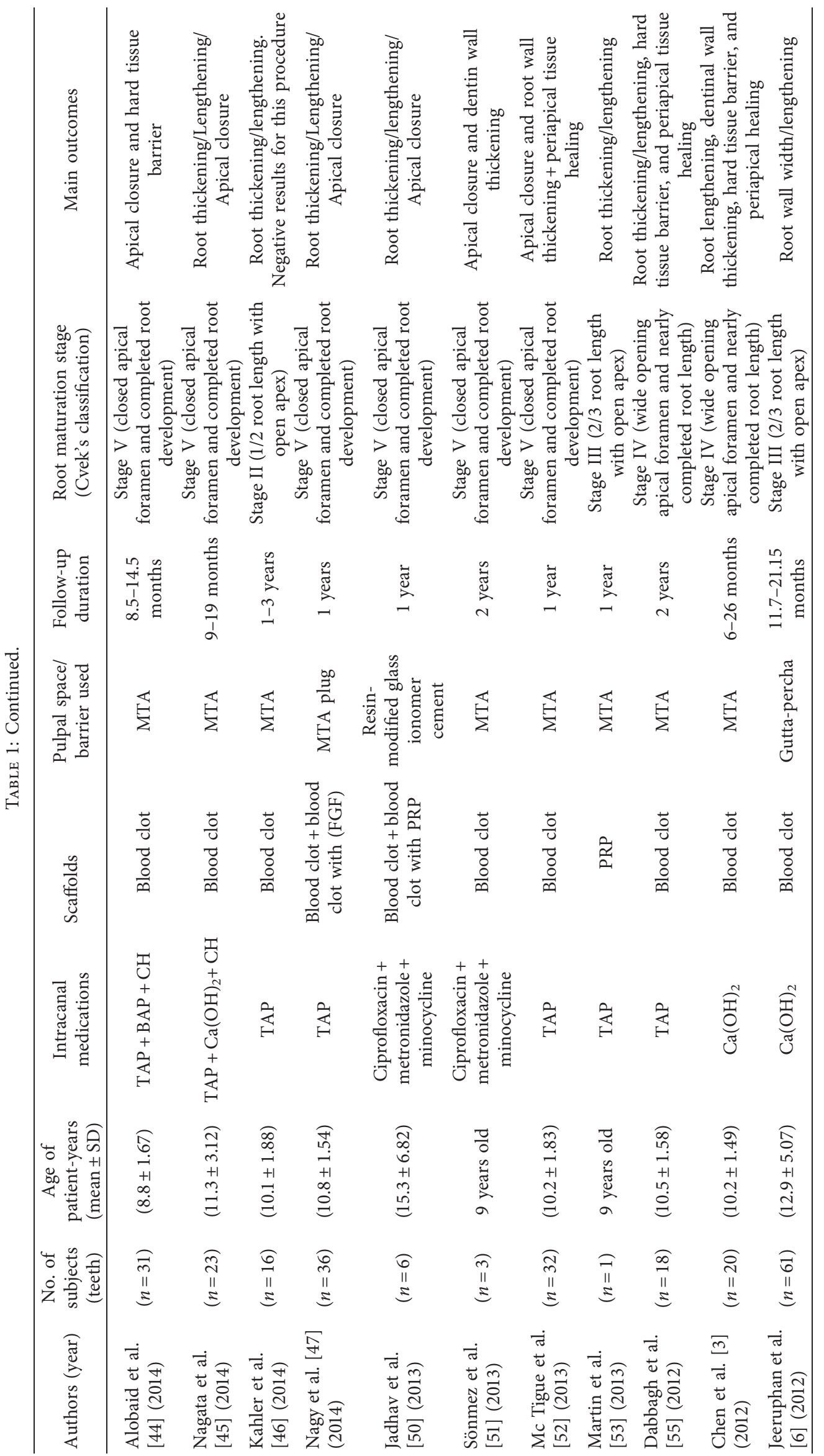




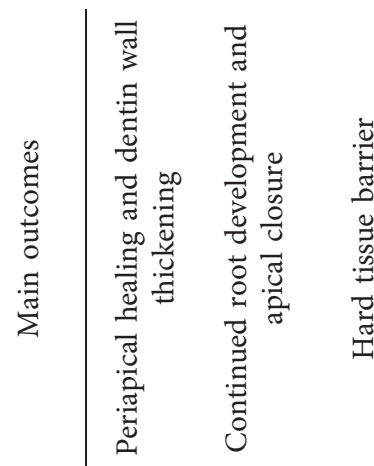

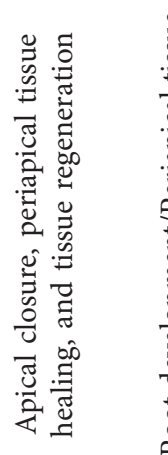

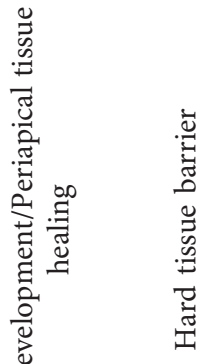

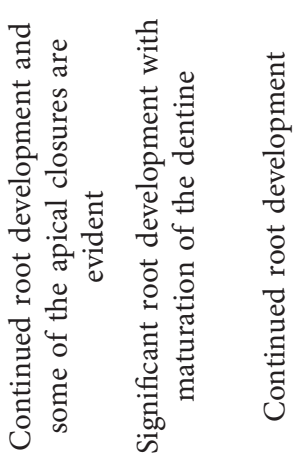

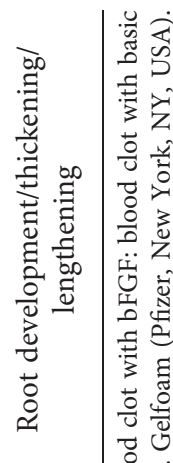

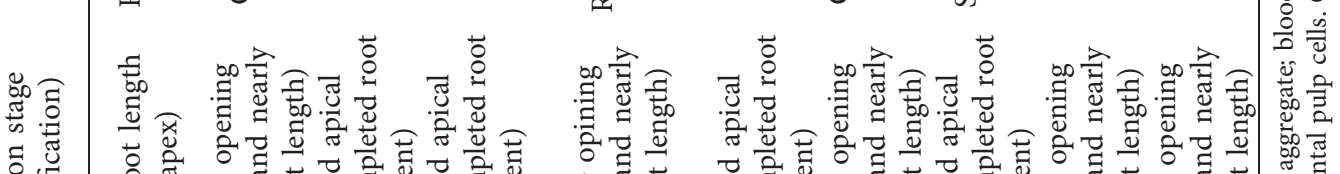

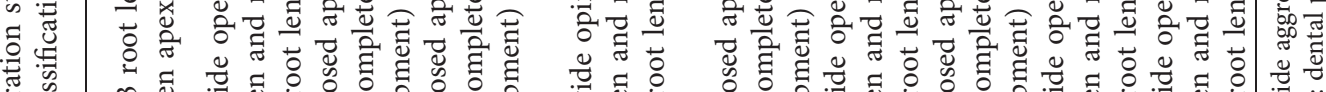

专密

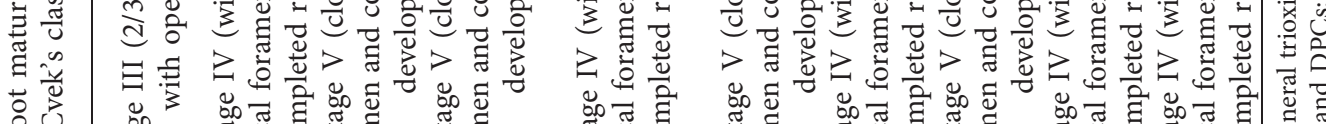

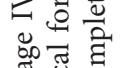

¿्व

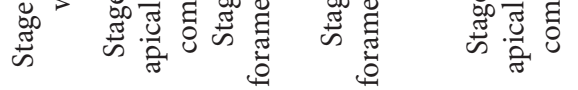

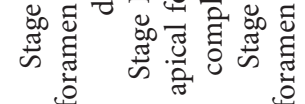

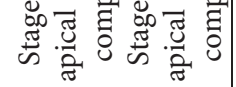

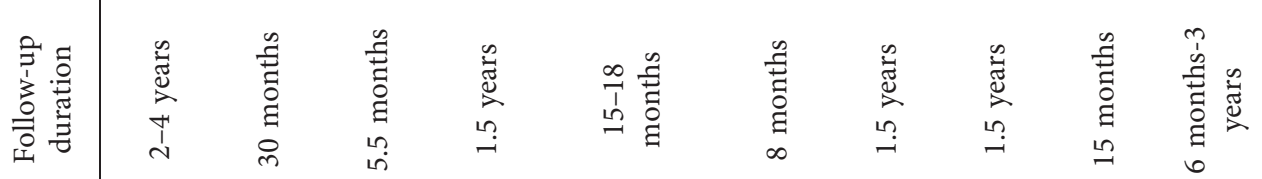

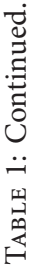

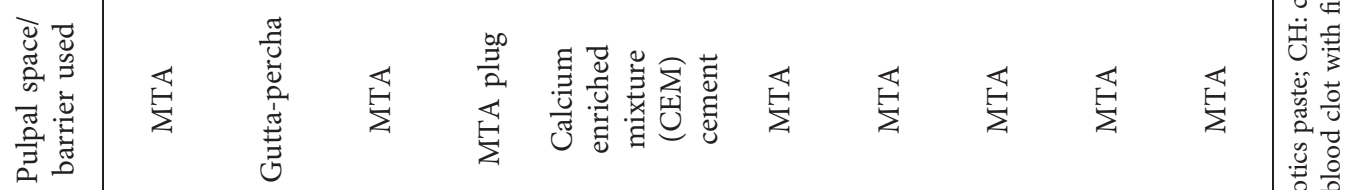

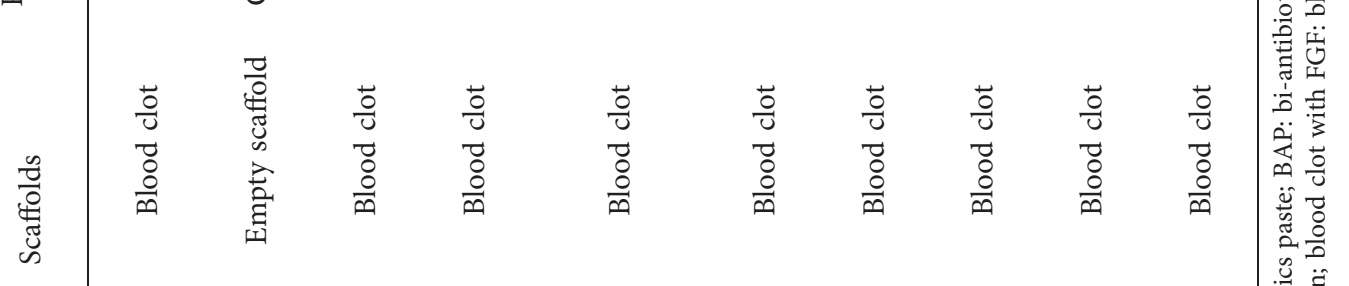

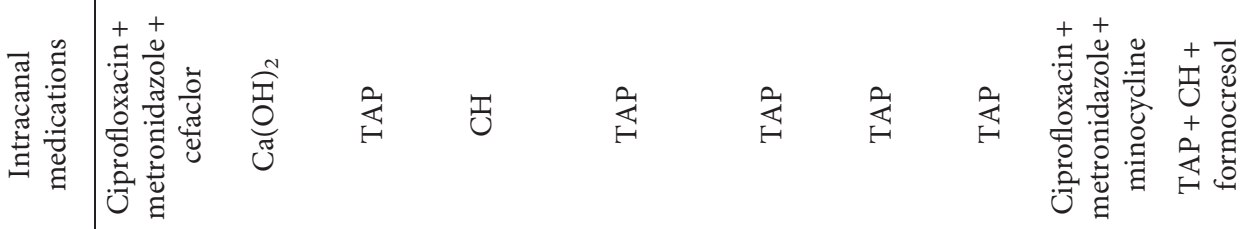

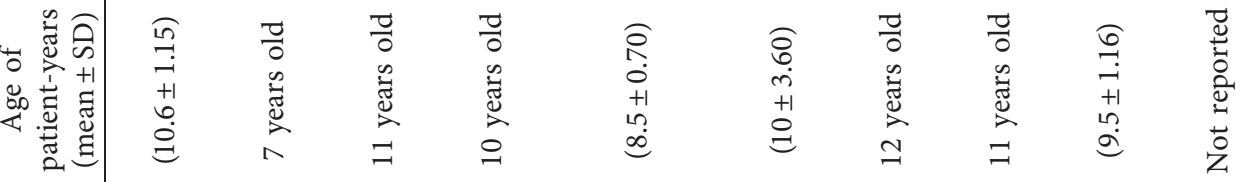

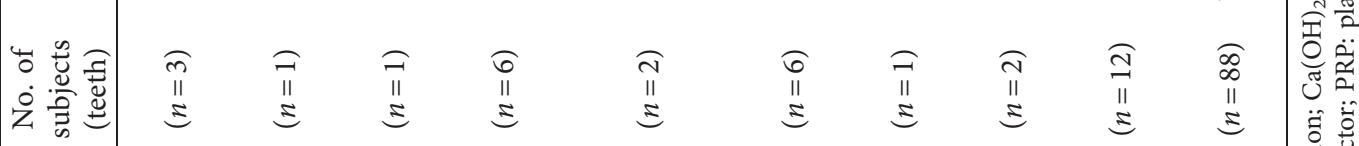

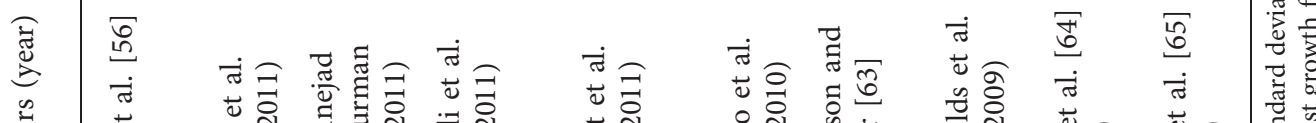

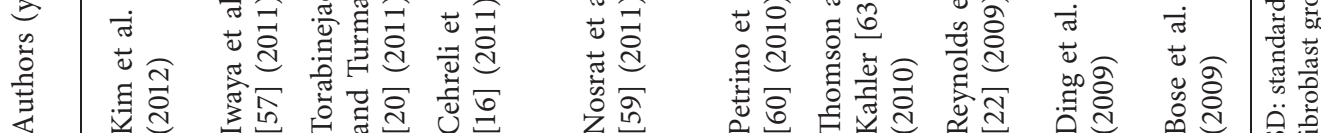




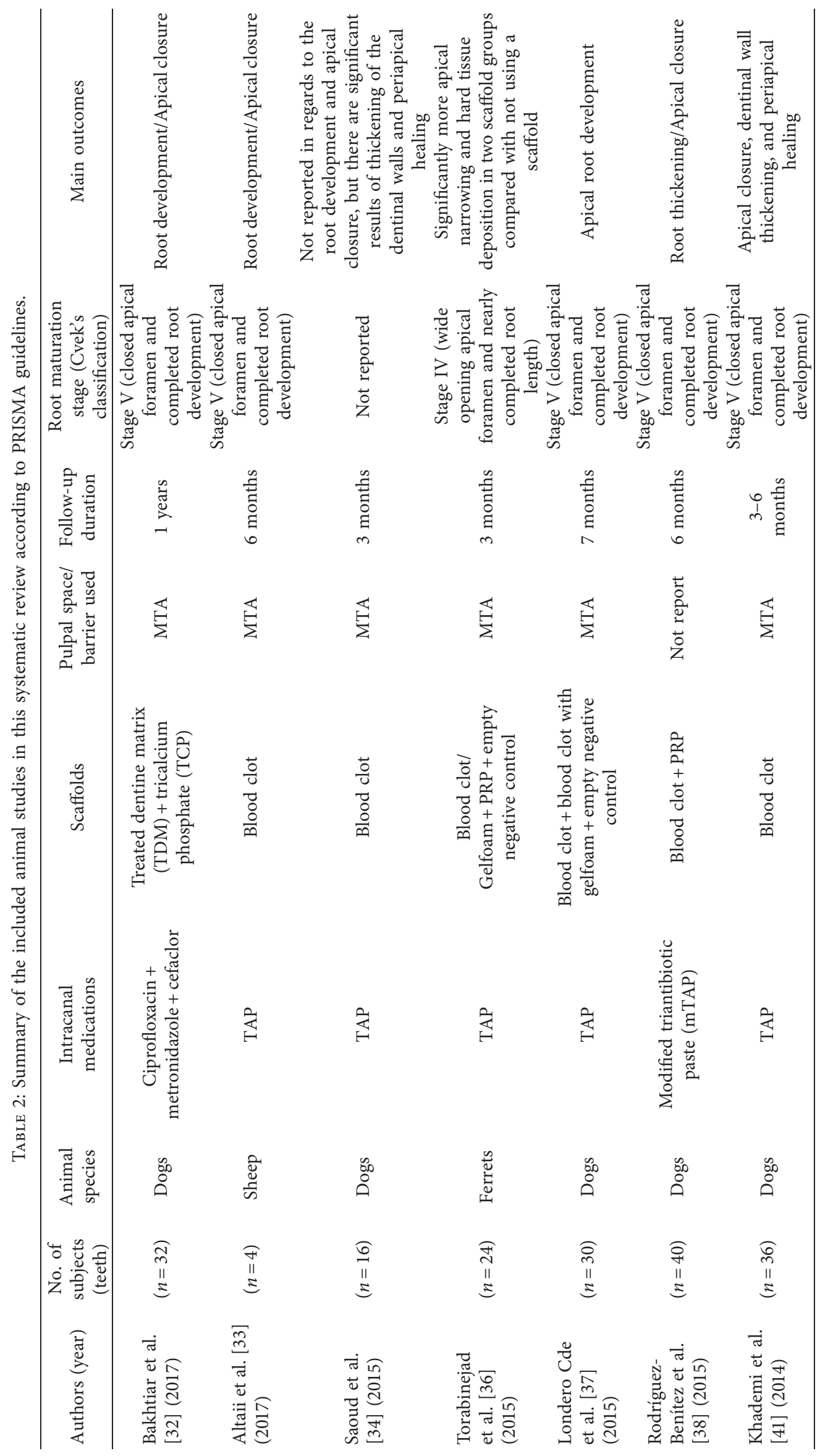




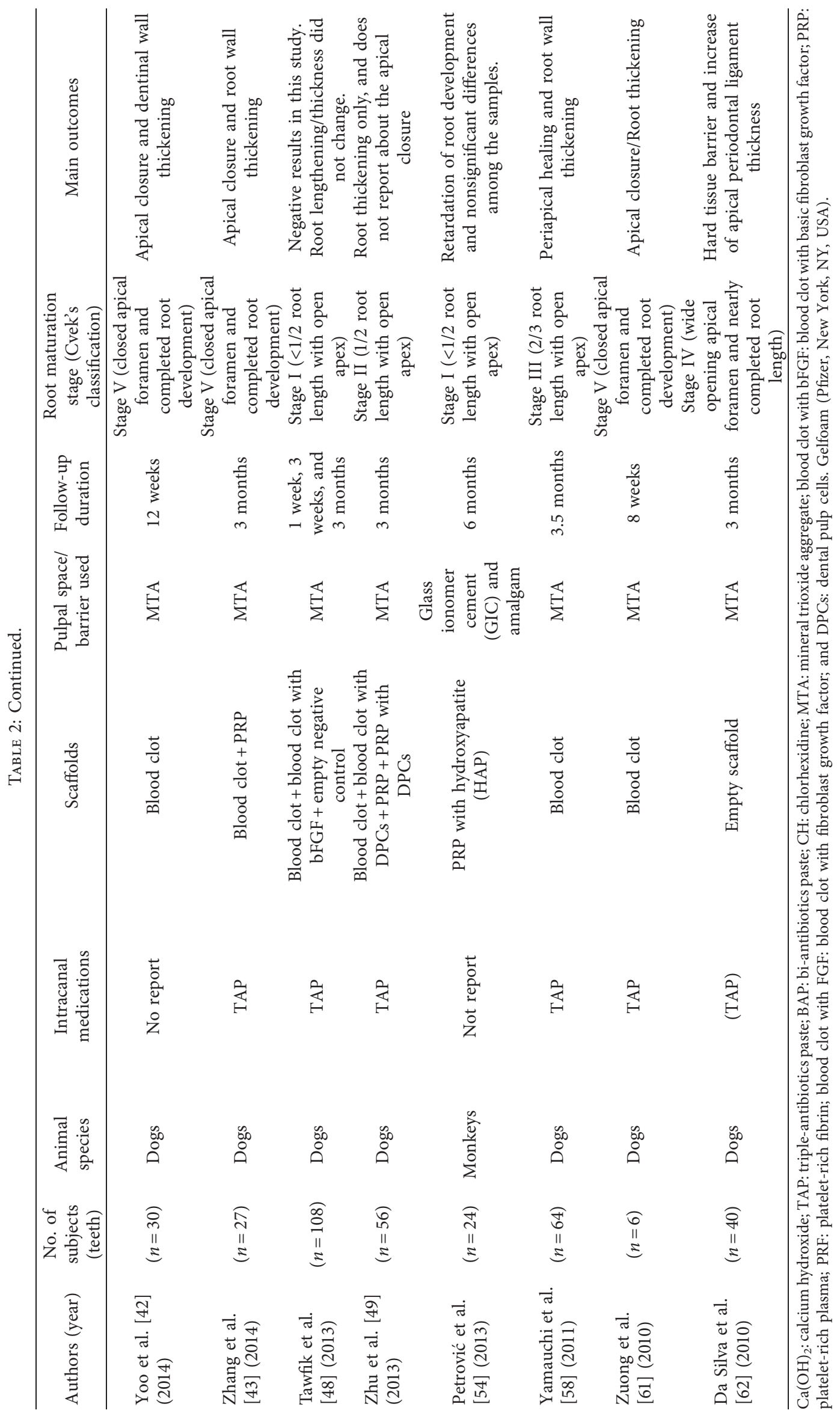


TABLE 3: Quality and risk Assessment of all the included studies in this systematic review.

\begin{tabular}{|c|c|c|c|c|c|c|c|}
\hline Study (year) & $\begin{array}{l}\text { Random } \\
\text { sequence } \\
\text { generation }\end{array}$ & $\begin{array}{c}\text { Allocation } \\
\text { concealment }\end{array}$ & $\begin{array}{c}\text { Defined } \\
\text { inclusion/ } \\
\text { exclusion }\end{array}$ & $\begin{array}{l}\text { Blinding of } \\
\text { outcome } \\
\text { assessment }\end{array}$ & $\begin{array}{c}\text { Incomplete } \\
\text { outcome data }\end{array}$ & $\begin{array}{l}\text { Selective } \\
\text { reporting }\end{array}$ & $\begin{array}{c}\text { Other } \\
\text { sources of } \\
\text { bias }\end{array}$ \\
\hline $\begin{array}{l}\text { Alasqah et al. [26] } \\
(2020)\end{array}$ & + & + & + & + & + & + & + \\
\hline $\begin{array}{l}\text { Rizk et al. [27] } \\
\text { (2019) }\end{array}$ & + & + & + & + & + & $?$ & + \\
\hline $\begin{array}{l}\text { Ajram et al. [28] } \\
(2019)\end{array}$ & + & + & + & + & + & + & + \\
\hline $\begin{array}{l}\text { Ulusoy and Cehreli } \\
\text { [29] (2017) }\end{array}$ & + & + & + & $?$ & + & + & $?$ \\
\hline $\begin{array}{l}\text { Moodley et al. [30] } \\
\text { (2017) }\end{array}$ & $?$ & + & + & + & + & + & + \\
\hline $\begin{array}{l}\text { Timmerman and } \\
\text { Parashos [31] (2017) }\end{array}$ & + & + & + & + & + & + & + \\
\hline $\begin{array}{l}\text { Bakhtiar et al. [32] } \\
\text { (2017) }\end{array}$ & + & + & + & + & + & + & + \\
\hline $\begin{array}{l}\text { Altaii et al. [33] } \\
\text { (2017) }\end{array}$ & + & + & + & + & + & + & + \\
\hline $\begin{array}{l}\text { Saoud et al. [34] } \\
\text { (2015) }\end{array}$ & + & + & + & + & $?$ & + & + \\
\hline $\begin{array}{l}\text { Nosrat et al. [35] } \\
(2015)\end{array}$ & $?$ & $?$ & + & + & + & + & + \\
\hline $\begin{array}{l}\text { Torabinejad et al. } \\
\text { [36] (2015) }\end{array}$ & + & + & + & + & + & + & + \\
\hline $\begin{array}{l}\text { Londero Cde et al. } \\
\text { [37] (2015) }\end{array}$ & + & + & + & + & + & $?$ & $?$ \\
\hline $\begin{array}{l}\text { Rodríguez-Benítez } \\
\text { et al. [38] (2015) }\end{array}$ & + & + & + & + & + & + & + \\
\hline $\begin{array}{l}\text { Bezgin et al. [39] } \\
\text { (2015) }\end{array}$ & + & + & + & + & + & + & + \\
\hline $\begin{array}{l}\text { Narang et al. [40] } \\
\text { (2015) }\end{array}$ & + & + & + & + & + & + & + \\
\hline $\begin{array}{l}\text { Saoud et al. [4] } \\
\text { (2014) }\end{array}$ & + & + & + & + & + & + & + \\
\hline $\begin{array}{l}\text { Khademi et al. [41] } \\
\text { (2014) }\end{array}$ & + & + & + & + & + & + & + \\
\hline Yoo et al. [42] (2014) & + & + & + & + & + & + & + \\
\hline $\begin{array}{l}\text { Zhang et al. [43] } \\
\text { (2014) }\end{array}$ & + & + & + & + & + & + & + \\
\hline $\begin{array}{l}\text { Alobaid et al. [44] } \\
\text { (2014) }\end{array}$ & + & + & + & + & + & + & + \\
\hline $\begin{array}{l}\text { Nagata et al. [45] } \\
(2014)\end{array}$ & + & + & + & + & + & + & + \\
\hline $\begin{array}{l}\text { Kahler et al. [46] } \\
\text { (2014) }\end{array}$ & + & + & + & + & + & + & + \\
\hline $\begin{array}{l}\text { Nagy et al. [47] } \\
(2014)\end{array}$ & + & + & + & + & + & + & + \\
\hline $\begin{array}{l}\text { Tawfik et al. [48] } \\
\text { (2013) }\end{array}$ & + & + & + & + & $?$ & + & $?$ \\
\hline Zhu et al. [49] (2013) & + & + & + & + & + & $?$ & + \\
\hline $\begin{array}{l}\text { Jadhav et al. [50] } \\
\text { (2013) }\end{array}$ & + & + & + & + & + & + & + \\
\hline $\begin{array}{l}\text { Sönmez et al. [51] } \\
\text { (2013) }\end{array}$ & + & + & + & + & + & + & + \\
\hline $\begin{array}{l}\text { Mc Tigue et al. [52] } \\
\text { (2013) }\end{array}$ & + & + & + & + & + & + & + \\
\hline $\begin{array}{l}\text { Martin et al. [53] } \\
\text { (2013) }\end{array}$ & + & + & + & + & + & + & + \\
\hline $\begin{array}{l}\text { Petrović et al. [54] } \\
\text { (2013) }\end{array}$ & + & + & + & + & + & + & + \\
\hline
\end{tabular}


TABLE 3: Continued.

\begin{tabular}{|c|c|c|c|c|c|c|c|}
\hline Study (year) & $\begin{array}{c}\text { Random } \\
\text { sequence } \\
\text { generation }\end{array}$ & $\begin{array}{c}\text { Allocation } \\
\text { concealment }\end{array}$ & $\begin{array}{l}\text { Defined } \\
\text { inclusion/ } \\
\text { exclusion }\end{array}$ & $\begin{array}{l}\text { Blinding of } \\
\text { outcome } \\
\text { assessment }\end{array}$ & $\begin{array}{l}\text { Incomplete } \\
\text { outcome data }\end{array}$ & $\begin{array}{l}\text { Selective } \\
\text { reporting }\end{array}$ & $\begin{array}{c}\text { Other } \\
\text { sources of } \\
\text { bias }\end{array}$ \\
\hline $\begin{array}{l}\text { Dabbagh et al. } \\
\text { (2012) [55] }\end{array}$ & + & + & + & + & + & + & + \\
\hline Chen et al. [3] (2012) & + & + & + & + & + & + & + \\
\hline $\begin{array}{l}\text { Jeeruphan et al. [6] } \\
(2012)\end{array}$ & + & + & + & + & + & + & + \\
\hline $\begin{array}{l}\text { Kim et al. [56] } \\
(2012)\end{array}$ & + & + & + & + & + & + & + \\
\hline $\begin{array}{l}\text { Iwaya et al. [57] } \\
\text { (2011) }\end{array}$ & + & + & + & + & + & + & + \\
\hline $\begin{array}{l}\text { Torabinejad and } \\
\text { Turman [20] (2011) }\end{array}$ & + & + & + & + & + & + & + \\
\hline $\begin{array}{l}\text { Cehrelli et al. [16] } \\
\text { (2011) }\end{array}$ & + & + & + & + & + & + & + \\
\hline $\begin{array}{l}\text { Yamauchi et al. [58] } \\
\text { (2011) }\end{array}$ & + & + & + & + & + & + & + \\
\hline $\begin{array}{l}\text { Nosrat et al. [59] } \\
\text { (2011) }\end{array}$ & + & + & + & + & + & + & + \\
\hline $\begin{array}{l}\text { Petrino et al. [60] } \\
(2010)\end{array}$ & + & + & + & + & + & + & + \\
\hline $\begin{array}{l}\text { Zuong et al. [61] } \\
(2010)\end{array}$ & + & + & + & + & + & + & + \\
\hline $\begin{array}{l}\text { Da Silva et al. [62] } \\
\text { (2010) }\end{array}$ & + & + & + & + & + & + & + \\
\hline $\begin{array}{l}\text { Thomson and } \\
\text { Kahler [63] (2010) }\end{array}$ & + & + & + & + & + & + & + \\
\hline $\begin{array}{l}\text { Reynolds et al. [22] } \\
(2009)\end{array}$ & + & + & + & + & + & + & + \\
\hline $\begin{array}{l}\text { Ding et al. [64] } \\
(2009)\end{array}$ & + & + & + & + & + & + & + \\
\hline $\begin{array}{l}\text { Bose et al. [65] } \\
\text { (2009) }\end{array}$ & + & + & + & + & $?$ & $?$ & + \\
\hline
\end{tabular}

$+=$ low risk; ? = unclear risk; and $-=$ high risk.

TABLE 4: Summary of all old systematic reviews in the scope of our systematic review.

\begin{tabular}{|c|c|c|c|c|}
\hline Authors & Year & $\begin{array}{l}\text { Number of } \\
\text { studies used }\end{array}$ & Method summary & Main conclusions \\
\hline $\begin{array}{l}\text { Bucchi et al. } \\
{[66]}\end{array}$ & 2017 & 23 studies & $\begin{array}{l}\text { The systematic review summaries and presents } \\
\text { different clinical and animal studies performed. } \\
\text { Only those articles published up to May } 2016 \\
\text { were considered for review. Using } 7 \text { different } \\
\text { databases (MEDLINE, Scopus, Cochrane library, } \\
\text { SciELO, Google Scholar, Science Direct, and } \\
\text { EMBASE), an electronic search was performed. }\end{array}$ & $\begin{array}{l}\text { Most of the included studies did not follow a } \\
\text { standard clinical protocol for regenerative } \\
\text { endodontic therapy. }\end{array}$ \\
\hline $\begin{array}{l}\text { Antunes } \\
\text { et al. [67] }\end{array}$ & 2016 & 11 studies & $\begin{array}{l}\text { A systematic review summarizes and presents } \\
\text { original articles in the database Web of Science, } \\
\text { PubMed, BVS (Medline, SciELO, Lilacs, and } \\
\text { BBO), Scopus, and Cochrane. Only those articles } \\
\text { published up to July } 2014 \text { were considered for } \\
\text { review, and analysis of the papers published } \\
\text { during this period took place based on previously } \\
\text { established criteria, through the methodology of } \\
\text { a systematic review. }\end{array}$ & $\begin{array}{l}\text { Significant outcomes have appeared in the pulp } \\
\text { revascularization, but several aspects remain } \\
\text { unknown, such as the key factors of this repair, the } \\
\text { type of tissue formed, and the long-term prognosis. }\end{array}$ \\
\hline
\end{tabular}


Interestingly, only 6 studies reported negative outcomes related to the clinical outcomes of endodontic regeneration therapy in the management of these teeth $[29,34,46,48,49,54]$. Although the results obtained from the included studies in this review confirm the success of this procedure in the management of immature necrotic permanent teeth in 40 studies ((Table 1 ) and (Table 2)). This warrants future randomized controlled clinical trials that scrutinize each clinical protocol with long-term outcomes of endodontic regenerative therapy and its clinical success in the management of these teeth.

\section{Conclusions}

This systematic review concluded that endodontic regenerative therapy showed better results in certain parameters such as increase in root wall lengthening and thickening, acute/chronic periapical lesions healing, and improved apical closure formation in the management of immature necrotic permanent teeth. In addition, there was considerable homogeneity among the included studies; so, conclusive results suggestive of their evidence towards the superiority of endodontic regenerative therapy in treating these kinds of teeth were compared with other treatment options. However, more clinical trials with a standardized protocol and defined clinical, radiographic, and histopathological outcomes with longer follow-up periods are warranted.

\section{Data Availability}

The data used to support the findings of this study are included within the article.

\section{Conflicts of Interest}

The authors declare that there are no conflicts of interest regarding the publication of this paper.

\section{Authors' Contributions}

Faisal T. Alghamdi was involved in research concept, research design, and wrote the original draft. Faisal T. Alghamdi and Alaa E. Alqurashi were involved in collection and/or assembly of data, in data analysis and interpretation, in writing the review and editing, and in the critical revision of the article, and finally approved the article.

\section{References}

[1] P. McCabe, "Revascularization of an immature tooth with apical periodontitis using a single visit protocol: a case report," International Endodontic Journal, vol. 48, no. 5, pp. 484-497, 2015.

[2] A. Diogenes, N. B. Ruparel, Y. Shiloah, and K. M. Hargreaves, "Regenerative endodontics: a way forward," Journal of the American Dental Association, vol. 147, no. 5, pp. 372-380, 2016.

[3] M. Y.-H. Chen, K.-L. Chen, C.-A. Chen, F. Tayebaty, P. A. Rosenberg, and L. M. Lin, "Responses of immature permanent teeth with infected necrotic pulp tissue and apical periodontitis/abscess to revascularization procedures,"
International Endodontic Journal, vol. 45, no. 3, pp. 294-305, 2012.

[4] T. M. A. Saoud, A. Zaazou, A. Nabil, S. Moussa, L. M. Lin, and J. L. Gibbs, "Clinical and radiographic outcomes of traumatized immature permanent necrotic teeth after revascularization/revitalization therapy," Journal of Endodontics, vol. 40, no. 12, pp. 1946-1952, 2014.

[5] J. O. Andreasen, B. Farik, and E. C. Munksgaard, "Long-term calcium hydroxide as a root canal dressing may increase risk of root fracture," Dental Traumatology: Official Publication of International Association for Dental Traumatology, vol. 18, no. 3, pp. 134-137, 2002.

[6] T. Jeeruphan, J. Jantarat, K. Yanpiset, L. Suwannapan, P. Khewsawai, and K. M. Hargreaves, "Mahidol study 1: comparison of radiographic and survival outcomes of immature teeth treated with either regenerative endodontic or apexification methods: a retrospective study," Journal of Endodontics, vol. 38, no. 10, pp. 1330-1336, 2012.

[7] K. Vidal, G. Martin, O. Lozano, M. Salas, J. Trigueros, and G. Aguilar, "Apical closure in apexification: a review and case report of apexification treatment of an immature permanent tooth with biodentine," Journal of Endodontics, vol. 42, no. 5, pp. 730-734, 2016.

[8] E. C. Sheehy and G. J. Roberts, "Use of calcium hydroxide for apical barrier formation and healing in non-vital immature permanent teeth: a review," British Dental Journal, vol. 183, no. 7, pp. 241-246, 1997.

[9] P. V. Abbott, "Apexification with calcium hydroxide-when should the dressing be changed? the case for regular dressing changes," Australian Endodontic Journal, vol. 24, no. 1, pp. 27-32, 1998.

[10] M. Rafter, “Apexification: a review," Dental Traumatology: Official Publication of International Association for Dental Traumatology, vol. 21, no. 1, pp. 1-8, 2005.

[11] M. Parirokh and M. Torabinejad, "Mineral trioxide aggregate: a comprehensive literature review-part III: clinical applications, drawbacks, and mechanism of action," Journal of Endodontics, vol. 36, no. 3, pp. 400-413, 2010.

[12] J. Mente, N. Hage, T. Pfefferle et al., "Mineral trioxide aggregate apical plugs in teeth with open apical foramina: a retrospective analysis of treatment outcome," Journal of Endodontics, vol. 35, no. 10, pp. 1354-1358, 2009.

[13] S. Simon, F. Rilliard, A. Berdal, and P. Machtou, "The use of mineral trioxide aggregate in one-visit apexification treatment: a prospective study," International Endodontic Journal, vol. 40, no. 3, pp. 186-197, 2007.

[14] D. E. Witherspoon, J. C. Small, J. D. Regan, and M. Nunn, "Retrospective analysis of open apex teeth obturated with mineral trioxide aggregate," Journal of Endodontics, vol. 34, no. 10, pp. 1171-1176, 2008.

[15] S. Sarris, J. F. Tahmassebi, M. S. Duggal, and I. A. Cross, “A clinical evaluation of mineral trioxide aggregate for root-end closure of non-vital immature permanent incisors in children-a pilot study," Dental Traumatology, vol. 24, no. 1, pp. 79-85, 2008.

[16] Z. C. Cehreli, S. Sara, S. Uysal, and M. D. Turgut, "MTA apical plugs in the treatment of traumatized immature teeth with large periapical lesions," Dental Traumatology: Official Publication of International Association for Dental Traumatology, vol. 27, no. 1, pp. 59-62, 2011.

[17] G. T.-J. Huang, "Apexification: the beginning of its end," International Endodontic Journal, vol. 42, no. 10, pp. 855-866, 2009. 
[18] X. Wang, B. Thibodeau, M. Trope, L. M. Lin, and G. T.-J. Huang, "Histologic characterization of regenerated tissues in canal space after the revitalization/revascularization procedure of immature dog teeth with apical periodontitis," Journal of Endodontics, vol. 36, no. 1, pp. 56-63, 2010.

[19] F. Banchs and M. Trope, "Revascularization of immature permanent teeth with apical periodontitis: new treatment protocol?" Journal of Endodontics, vol. 30, no. 4, pp. 196-200, 2004.

[20] M. Torabinejad and M. Turman, "Revitalization of tooth with necrotic pulp and open apex by using platelet-rich plasma: a case report," Journal of Endodontics, vol. 37, no. 2, pp. 265268, 2011.

[21] L. M. Lin and B. Kahler, "A review of regenerative endodontics: current protocols and future directions," Journal of Istanbul University Faculty of Dentistry, vol. 51, no. 3 Suppl 1, pp. S41-s51, 2017.

[22] K. Reynolds, J. D. Johnson, and N. Cohenca, "Pulp revascularization of necrotic bilateral bicuspids using a modified novel technique to eliminate potential coronal discolouration: a case report," International Endodontic Journal, vol. 42, no. 1, pp. 84-92, 2009.

[23] K. M. Hargreaves, T. Geisler, M. Henry, and Y. Wang, "Regeneration potential of the young permanent tooth: what does the future hold?" Journal of Endodontics, vol. 34, no. 7, pp. S51-S56, 2008.

[24] D. Moher, A. Liberati, J. Tetzlaff, D. G. Altman, and P. G. The, "Preferred reporting items for systematic reviews and metaanalyses: the PRISMA statement," PLoS Medicine, vol. 6, no. 7, Article ID e1000097, 2009.

[25] J. Higgins and S. Green, Cochrane Handbook for Systematic Reviews of Interventions Version 5.1.0, The Cochrane Collaboration, London, UK, 2011.

[26] M. Alasqah, S. I. R. Khan, K. Alfouzan, and A. Jamleh, "Regenerative endodontic management of an immature molar using calcium hydroxide and triple antibiotic paste: a twoyear follow-up," Case Reports in Dentistry, vol. 2020, Article ID 9025847, 5 pages, 2020.

[27] H. M. Rizk, M. S. S. Al-Deen, and A. A. Emam, "Regenerative endodontic treatment of bilateral necrotic immature permanent maxillary central incisors with platelet-rich plasma versus blood clot: a split mouth double-blinded randomized controlled trial," International Journal of Clinical Pediatric Dentistry, vol. 12, no. 4, pp. 332-339, 2019.

[28] J. Ajram, I. Khalil, R. Gergi, and C. Zogheib, "Management of an immature necrotic permanent molar with apical periodontitis treated by regenerative endodontic protocol using calcium hydroxide and MM-MTA: a case report with two years follow up," Dentistry Journal, vol. 7, no. 1, 2019.

[29] A. T. Ulusoy and Z. C. Cehreli, "Regenerative endodontic treatment of necrotic primary molars with missing premolars: a case series," Pediatric Dentistry, vol. 39, no. 3, pp. 131-134, 2017.

[30] D. Moodley, C. Peck, T. Moodley, and N. Patel, "Management of necrotic pulp of immature permanent incisor tooth: a regenerative endodontic treatment protocol: case report," South African Dental Journal, vol. 72, pp. 122-125, 2017.

[31] A. Timmerman and P. Parashos, "Delayed root development by displaced mineral trioxide aggregate after regenerative endodontics: a case report," Journal of Endodontics, vol. 43, no. 2, pp. 252-256, 2017.

[32] H. Bakhtiar, H. Mirzaei, M. R. Bagheri et al., "Histologic tissue response to furcation perforation repair using mineral trioxide aggregate or dental pulp stem cells loaded onto treated dentin matrix or tricalcium phosphate," Clinical Oral Investigations, vol. 21, no. 5, pp. 1579-1588, 2017.

[33] M. Altaii, P. Cathro, M. Broberg, and L. Richards, "Endodontic regeneration and tooth revitalization in immature infected sheep teeth," International Endodontic Journal, vol. 50, no. 5, pp. 480-491, 2017.

[34] T. M. A. Saoud, A. Zaazou, A. Nabil et al., "Histological observations of pulpal replacement tissue in immature dog teeth after revascularization of infected pulps," Dental Traumatology: Official Publication of International Association for Dental Traumatology, vol. 31, no. 3, pp. 243-249, 2015.

[35] A. Nosrat, A. Kolahdouzan, F. Hosseini, E. A. Mehrizi, P. Verma, and M. Torabinejad, "Histologic outcomes of uninfected human immature teeth treated with regenerative endodontics: 2 case reports," Journal of Endodontics, vol. 41, no. 10, pp. 1725-1729, 2015.

[36] M. Torabinejad, M. Milan, S. Shabahang, K. R. Wright, and H. Faras, "Histologic examination of teeth with necrotic pulps and periapical lesions treated with 2 scaffolds: an animal investigation," Journal of Endodontics, vol. 41, no. 6, pp. 846-852, 2015.

[37] C. d. L. D. Londero, C. M. L. Pagliarin, M. C. S. Felippe, W. T. Felippe, C. C. Danesi, and F. B. Barletta, "Histologic analysis of the influence of a gelatin-based scaffold in the repair of immature dog teeth subjected to regenerative endodontic treatment," Journal of Endodontics, vol. 41, no. 10, pp. 1619-1625, 2015.

[38] S. Rodríguez-Benítez, C. Stambolsky, J. L. Gutiérrez-Pérez, D. Torres-Lagares, and J. J. Segura-Egea, "Pulp revascularization of immature dog teeth with apical periodontitis using triantibiotic paste and platelet-rich plasma: a radiographic study," Journal of Endodontics, vol. 41, no. 8, pp. 1299-1304, 2015.

[39] T. Bezgin, A. D. Yilmaz, B. N. Celik, M. E. Kolsuz, and H. Sonmez, "Efficacy of platelet-rich plasma as a scaffold in regenerative endodontic treatment," Journal of Endodontics, vol. 41, no. 1, pp. 36-44, 2015.

[40] I. Narang, N. Mittal, and N. Mishra, "A comparative evaluation of the blood clot, platelet-rich plasma, and platelet-rich fibrin in regeneration of necrotic immature permanent teeth: a clinical study," Contemporary Clinical Dentistry, vol. 6, no. 1, pp. 63-68, 2015.

[41] A. A. Khademi, O. Dianat, F. Mahjour, S. M. Razavi, and F. Younessian, "Outcomes of revascularization treatment in immature dog's teeth," Dental Traumatology, vol. 30, no. 5, pp. 374-379, 2014.

[42] Y.-J. Yoo, W. Lee, Y.-A. Cho, J.-C. Park, W.-J. Shon, and S.-H. Baek, "Effect of conditioned medium from preameloblasts on regenerative cellular differentiation of the immature teeth with necrotic pulp and apical periodontitis," Journal of Endodontics, vol. 40, no. 9, pp. 1355-1361, 2014.

[43] D.-D. Zhang, X. Chen, Z.-F. Bao, M. Chen, Z.-J. Ding, and M. Zhong, "Histologic comparison between platelet-rich plasma and blood clot in regenerative endodontic treatment: an animal study," Journal of Endodontics, vol. 40, no. 9, pp. 1388-1393, 2014.

[44] A. S. Alobaid, L. M. Cortes, J. Lo et al., "Radiographic and clinical outcomes of the treatment of immature permanent teeth by revascularization or apexification: a pilot retrospective cohort study," Journal of Endodontics, vol. 40, no. 8, pp. 1063-1070, 2014.

[45] J. Y. Nagata, B. P. Figueiredo de Almeida Gomes, T. F. Rocha Lima et al., "Traumatized immature teeth treated with 2 
protocols of pulp revascularization," Journal of Endodontics, vol. 40 , no. 5, pp. 606-612, 2014.

[46] B. Kahler, S. Mistry, A. Moule et al., "Revascularization outcomes: a prospective analysis of 16 consecutive cases," Journal of Endodontics, vol. 40, no. 3, pp. 333-338, 2014.

[47] M. M. Nagy, H. E. Tawfik, A. A. R. Hashem, and A. M. AbuSeida, "Regenerative potential of immature permanent teeth with necrotic pulps after different regenerative protocols," Journal of Endodontics, vol. 40, no. 2, pp. 192-198, 2014.

[48] H. Tawfik, A. M. Abu-Seida, A. A. Hashem, and M. M. Nagy, "Regenerative potential following revascularization of immature permanent teeth with necrotic pulps," International Endodontic Journal, vol. 46, no. 10, pp. 910-922, 2013.

[49] W. Zhu, X. Zhu, G. T.-J. Huang, G. S. P. Cheung, W. L. Dissanayaka, and C. Zhang, "Regeneration of dental pulp tissue in immature teeth with apical periodontitis using platelet-rich plasma and dental pulp cells," International Endodontic Journal, vol. 46, no. 10, pp. 962-970, 2013.

[50] G. R. Jadhav, N. Shah, and A. Logani, "Comparative outcome of revascularization in bilateral, non-vital, immature maxillary anterior teeth supplemented with or without platelet rich plasma: a case series," Journal of Conservative Dentistry: JCD, vol. 16, no. 6, pp. 568-572, 2013.

[51] I. Sönmez, A. Akbay Oba, and M. Erkmen Almaz, "Revascularızation/regeneration performed in immature molars: case reports," Journal of Clinical Pediatric Dentistry, vol. 37, no. 3, pp. 231-234, 2013.

[52] D. J. McTigue, K. Subramanian, and A. Kumar, "Case series: management of immature permanent teeth with pulpal necrosis: a case series," Pediatric Dentistry, vol. 35, no. 1, pp. 55-60, 2013.

[53] G. Martin, D. Ricucci, J. L. Gibbs, and L. M. Lin, "Histological findings of revascularized/revitalized immature permanent molar with apical periodontitis using platelet-rich plasma," Journal of Endodontics, vol. 39, no. 1, pp. 138-144, 2013.

[54] V. Petrovic, N. Pejcic, and S. Cakic, "The influence of different therapeutic modalities and platelet rich plasma on apexogenesis: a preliminary study in monkeys," Advances in Clinical and Experimental Medicine: Official Organ Wroclaw Medical University, vol. 22, no. 4, pp. 469-479, 2013.

[55] B. Dabbagh, E. Alvaro, D. D. Vu, J. Rizkallah, and S. Schwartz, "Clinical complications in the revascularization of immature necrotic permanent teeth," Pediatric Dentistry, vol. 34, no. 5, pp. 414-417, 2012.

[56] D.-S. Kim, H.-J. Park, J.-H. Yeom et al., "Long-term followups of revascularized immature necrotic teeth: three case reports," International Journal of Oral Science, vol. 4, no. 2, pp. 109-113, 2012.

[57] S.-i. Iwaya, M. Ikawa, and M. Kubota, "Revascularization of an immature permanent tooth with periradicular abscess after luxation," Dental Traumatology: Official Publication of International Association for Dental Traumatology, vol. 27, no. 1, pp. 55-58, 2011.

[58] N. Yamauchi, S. Yamauchi, H. Nagaoka et al., "Tissue engineering strategies for immature teeth with apical periodontitis," Journal of Endodontics, vol. 37, no. 3, pp. 390-397, 2011.

[59] A. Nosrat, A. Seifi, and S. Asgary, "Regenerative endodontic treatment (revascularization) for necrotic immature permanent molars: a review and report of two cases with a new biomaterial," Journal of Endodontics, vol. 37, no. 4, pp. 562567, 2011.

[60] J. A. Petrino, K. K. Boda, S. Shambarger, W. R. Bowles, and S. B. McClanahan, "Challenges in regenerative endodontics: a case series," Journal of Endodontics, vol. 36, no. 3, pp. 536-541, 2010.

[61] X. Y. Zuong, Y. P. Yang, W. X. Chen, Y. J. Zhang, and C. M. Wen, "Pulp revascularization of immature anterior teeth with apical periodontitis," Journal of Stomatology, vol. 28, no. 6, pp. 672-674, 2010.

[62] L. A. B. Da Silva, P. Nelson-Filho, R. A. B. Da Silva et al., "Revascularization and periapical repair after endodontic treatment using apical negative pressure irrigation versus conventional irrigation plus triantibiotic intracanal dressing in dogs' teeth with apical periodontitis," Oral Surgery, Oral Medicine, Oral Pathology, Oral Radiology, and Endodontology, vol. 109, no. 5, pp. 779-787, 2010.

[63] A. Thomson and B. Kahler, "Regenerative endodontics-biologically-based treatment for immature permanent teeth: a case report and review of the literature," Australian Dental Journal, vol. 55, no. 4, pp. 446-452, 2010.

[64] R. Y. Ding, G. S.-p. Cheung, J. Chen, X. Z. Yin, Q. Q. Wang, and C. F. Zhang, "Pulp revascularization of immature teeth with apical periodontitis: a clinical study," Journal of Endodontics, vol. 35, no. 5, pp. 745-749, 2009.

[65] R. Bose, P. Nummikoski, and K. Hargreaves, "A retrospective evaluation of radiographic outcomes in immature teeth with necrotic root canal systems treated with regenerative endodontic procedures," Journal of Endodontics, vol. 35, no. 10, pp. 1343-1349, 2009.

[66] C. Bucchi, I. Valdivia-Gandur, R. Sánchez-Bizjak, V. TallónWalton, and C. Manzanares-Céspedes, "Regenerative endodontic therapy: a systematic review of clinical protocols," International Journal of Clinical and Experimental Medicine, vol. 10, no. 3, pp. 2006-2015, 2017.

[67] L. S. Antunes, A. G. Salles, C. C. Gomes, T. B. Andrade, M. P. Delmindo, and L. A. A. Antunes, "The effectiveness of pulp revascularization in root formation of necrotic immature permanent teeth: a systematic review," Acta Odontologica Scandinavica, vol. 74, no. 3, pp. 161-169, 2016.

[68] V. Y. Shivashankar, D. A. Johns, R. K. Maroli et al., "Comparison of the effect of PRP, PRF, and induced bleeding in the revascularization of teeth with necrotic pulp and open apex: a triple blind randomized clinical trial," Journal of Clinical and Diagnostic Research: JCDR, vol. 11, no. 6, pp. ZC34-ZC39, 2017.

[69] M. Cvek, "Prognosis of luxated nonvital maxillary incisors treated with calcium hydroxide and filled with gutta-percha. a retrospective clinical study," Dental Traumatology, vol. 8, no. 2, pp. 45-55, 1992. 